\title{
Do Mathematics, humour and teaching combine?
}

\author{
Luís Menezes $^{1 *}$, Ana Maria Costa ${ }^{2}$ \\ ${ }^{1}$ CI\&DETS/CIDEI, Polytechnic of Viseu, Portugal \\ ${ }^{2}$ CI\&DETS/CIDEI, Polytechnic of Viseu, Portugal
}

\section{ARTICLE INFO}

\section{Keywords:}

classroom, mathematics, education, teachers, humour.

\begin{abstract}
Mathematics is a very important school subject, but in many countries, such as Portugal and Spain, it has high levels of failure, together with low levels of student engagement. Therefore, mathematics teachers seek to find the best methods for teaching in order to achieve appropriate learning outcomes. Humour is a social element enjoyed by most people and is increasingly being used. Some of this humour focuses on Mathematics and mathematics classes. Many studies, involving different school subjects, namely mathematics, show the benefits of using humour to teach and learn. Therefore, we intend to respond to the following questions: Do Portuguese and Spanish mathematics teachers appreciate humour? Do they acknowledge its educational value for teaching mathematics? Do they use humour to teach mathematics? To answer this question, we designed a mixed methodology study with a sample of 1088 Iberian mathematics teachers (Portuguese and Spanish), that teach from the early years of education up to higher education. Data collection was done through an online questionnaire. The main results show that most teachers, at all levels of teaching, acknowledge that they have a sense of humour, also acknowledging its educational value and have already used it in their classes, with the goal of creating a positive learning environment (with an emotive function) and making students think and communicate (with a cognitive and communicative functions).
\end{abstract}

\section{Introduction}

This study focuses on the humour in mathematics teaching, trying to understand if Mathematics, humour and teaching combine for Portuguese and Spanish mathematics teachers. Thus, we seek to respond to the following questions: Do Portuguese and Spanish mathematics teachers appreciate humour? Do they acknowledge its educational value for teaching mathematics? Do they use humour to teach mathematics?

In order to answer these questions, we will begin by defining humour and understanding how it operates according to various theoreticians (Martin, 2007; Meyer, 2015; Perks, 2012). Then we

\footnotetext{
$\square$ Corresponding Author E-Mail Address: menezes@esev.ipv.pt
} 
discuss the educational value of humour ((Banas, Dunbar, Rodriguez \& Liu, 2011; Martin, 2007; Meyer, 2015; Perks, 2012), particularly in teaching mathematics, highlighting examples of mathematical tasks based on graphic humour (Flores \& Moreno, 2011; Guitart, 2011; Guitart \& Flores, 2003; Menezes \& Alves, 2019; NCTM, 2007, 2013). Finally, we describe the methodology and we present and discuss the results obtained by applying an online questionnaire.

\section{Focusing Humour}

\subsection{Concept and theories}

Everyone seems to know what humour is, but what is it in fact and what does it involve? Many authors have been dedicating themselves to the study of humour, since classical antiquity, like Plato, Aristotle, Cicero and Quintilian, to the present, in subjects such as, for example, philosophy, linguistics and psychology (Banas et al., 2011; Martins, 2015; Martin, 2007; Meyer, 2015; Perks, 2012). Despite the diversity of approaches to the issue, there are some aspects which gather consensus: humour is connected with comedy, good mood and laughter.

For Banas et al. (2011), "humour involves the communication of multiple, incongruous meanings that are amusing in some manner" (p. 117). These authors clarify that humour implies the intentional use of both verbal and nonverbal communication, and behaviours that elicit positive responses like laughter and joy (Banas et al., 2011). For Martin (2007), "humour is a broad term that refers to anything that people say or do that is perceived as funny and tends to make others laugh" (p. 5). The author also adds that humour corresponds to "mental processes that go into both creating and perceiving such as amusing stimulus and also the affective response involved in the enjoyment of it" (Martin, 2007, p. 5).

Why do we laugh? How does humour work? There are many theories, which rest upon different roots and show how humour happens. Relief, superiority and incongruity theories are among the most studied (Banas et al., 2011; Martin, 2007; Martins, 2015). In this study, we are mainly interested in the incongruity theory. According to the incongruity theory, people understand humour because they resolve the incongruity and they perceive this incongruity as funny (Adão, 2016; Banas et al., 2011).

The following comic strip (Figure 1) illustrates how humour works according to the incongruity theory. Using a daily situation in which a counting is performed, we are surprised at the unexpected end, as it uses rational numbers in an unusual way. We laugh if we solve the problem, that is, if we understand the goal of that strange way of counting. 
Figure 1: Comics by Ryan Kramer

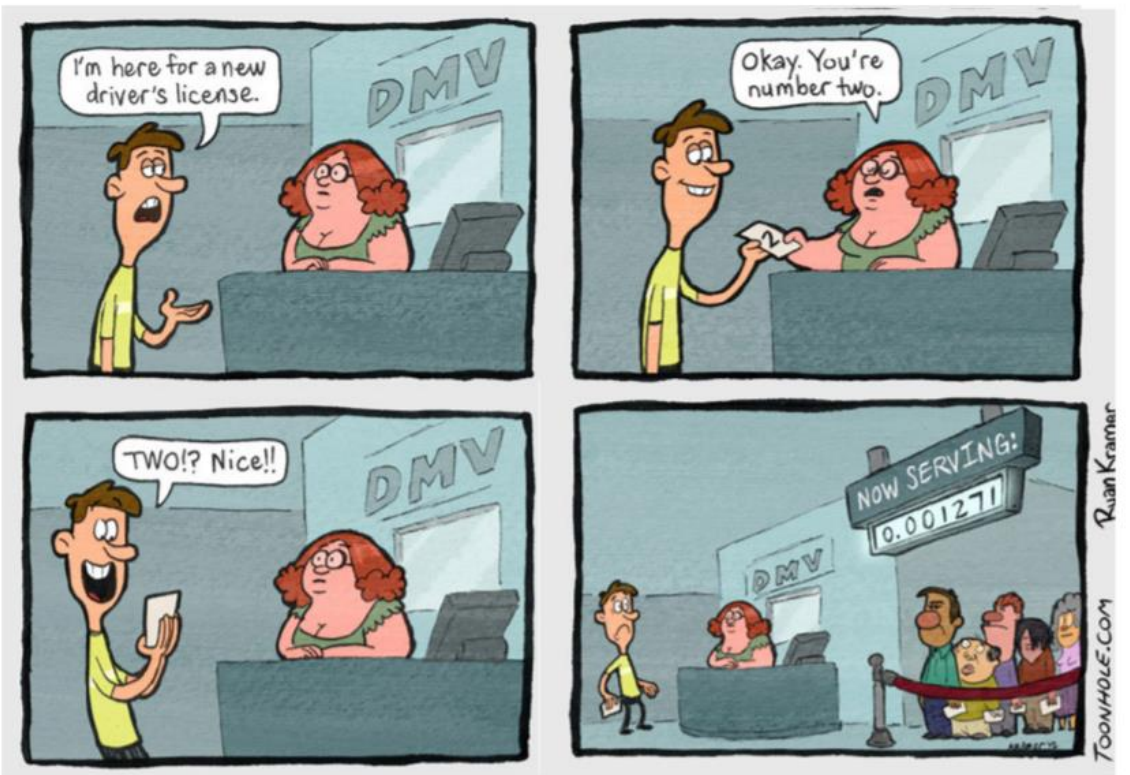

Source: (Menezes et al., 2019)

As in the previous case, also in figure 2 we have another adding up situation that is incongruous with the request made and what the reader would be expecting.

Figure 2: Comics by Chris Browne
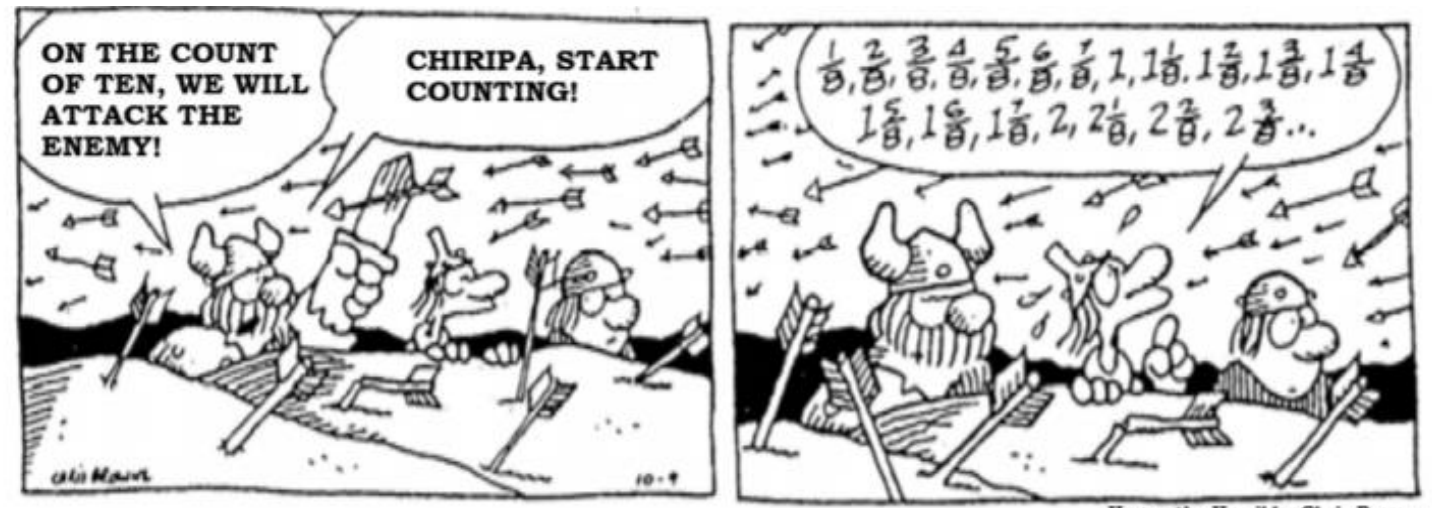

Source: (Menezes et al., 2019)

Hagar, the Horrible, Chris Browne

In this comic, we are surprised at the way of counting, as it uses rational numbers in the form of fractions. If there was no rationality in this way of counting numbers, the situation would be simply strange. But, in solving this situation, we laugh because we understand the cleverness of Chiripa, the character: Delay the attack for fear of the consequences. 


\subsection{Focusing humour on education}

Humour is a very common social form of behaviour, which is usually, much appreciated. What happens in educational terms? Is humour present inside the classrooms? Is it used for educational purposes? Martin (2007) points out that "evidence from several studies indicates that many teachers tend to use humour quite frequently in classrooms settings" (p. 351).

In evaluating over 40 years of research on humour in education, Banas et al. (2011) concludes that "humour is a prevalent communication behaviour in pedagogical contexts and promotes different purposes" (p. 137). These authors show that teachers mainly use humour to create a positive learning environment: "The use of positive, nonaggressive humour has been associated with a more interesting and relaxed learning environment, higher instructor evaluations, greater perceived motivation to learn, and enjoyment of the course." (p. 137). In the same way, Martin (2007) favours humour because it may be an effective tool to create a positive classroom environment and to facilitate teacher communication, and, consequently, student learning. For Banas et al. (2011), humour is also used by teachers because it can enhance and recall previously learnt subject-matters and also aid learning: "humorous information is recalled more easily than non-humorous information" (p. 137). So, humour, besides eliciting laughter, is socially influential/significant, which is very important for class communication and student learning. Therefore, some authors conclude that instructional humor performs three fundamental functions: (i) cognitive; (ii) affective; and (iii) communicative (Banas et al., 2011; Martin, 2007; Meyer, 2015). That is, humour: (i) focused on disciplinary content makes students think and build knowledge; (ii) triggers positive emotions that facilitate learning; and (iii) favours communication in class.

Is humour present in the teaching and learning of mathematics? Although in the last two decades, several authors have undertaken some work in this area (Flores \& Moreno, 2011; Guitart, 2012; Guitart \&Flores, 2003; Menezes \& Alves, 2019; NCTM, 2007, 2013; Shmakov \& Hannula, 2010), plenty of empirical studies are not yet available. In order to have empirical studies centred on the use of humour to teach and to make students think mathematically, it is necessary to create good mathematical tasks and prepare teachers for their use.

The book "Humour in Mathematics Teaching: tasks for the classroom" (Menezes et al., 2019), developed within the scope of HUMAT Research Project (Humour in Mathematics Teaching), seeks to contribute to these goals, comprising two sections. The former presents an introduction to instructional humour. The latter is dedicated to the presentation of mathematical tasks, alongside with teaching instructions for teachers. As an example, we present two tasks (Figures 3 and 4 ) that rely upon the comics of Figures 1 and 2. 
Figure 3: Task "When number two is not a big a deal..."

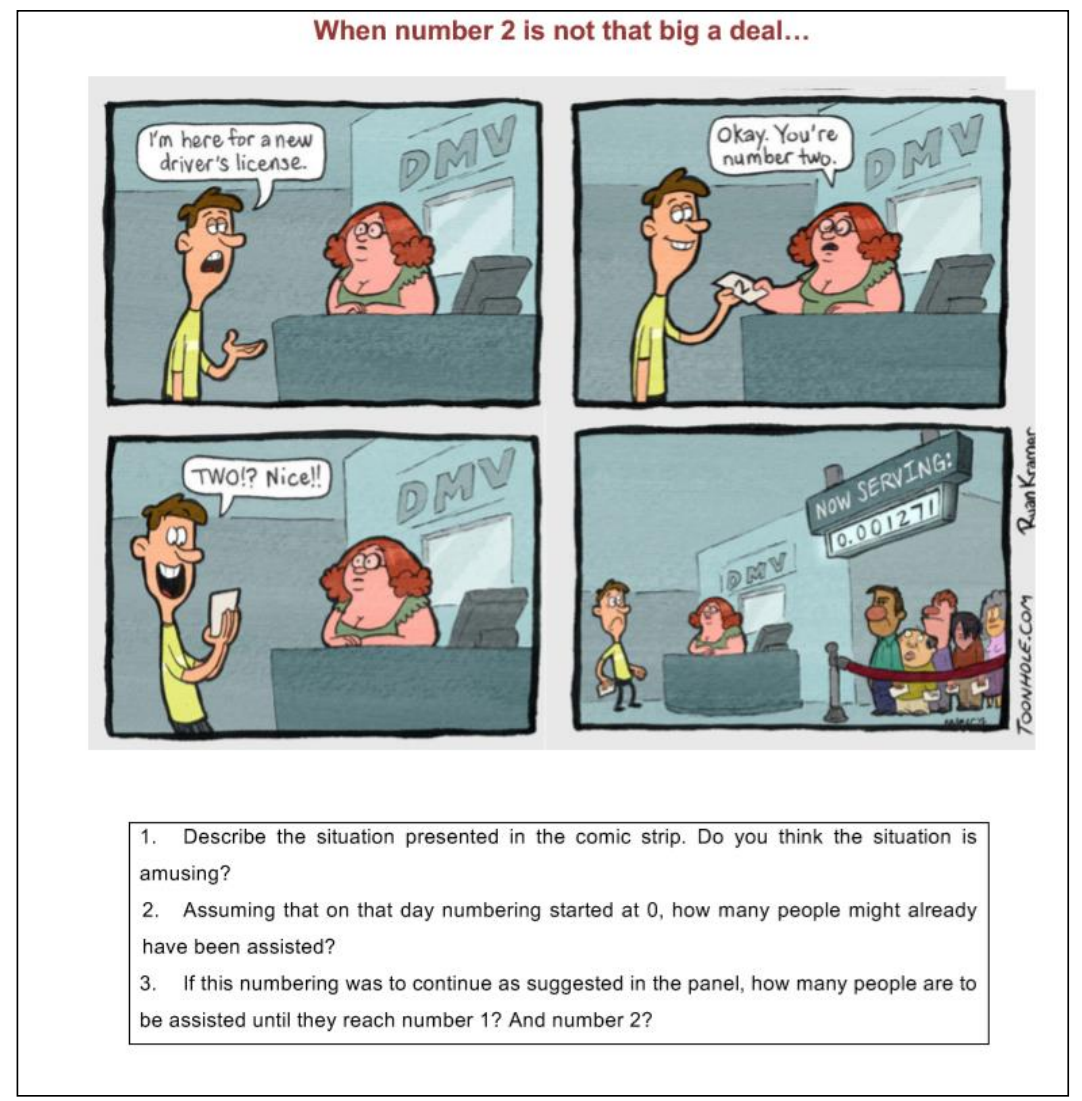

Source: (Menezes et al., 2019)

Figure 4: Task "Attack!"

1. Describe the situation depicted in the comic strip. What could have been the intention of
the protagonist? What strategy did he use? Do you consider this situation funny?
2. How many numbers does Lucky Eddie have to enumerate before he attacks the enemy?
What kind of numbers did he use? And which representations occur?
3. How could he reduce the waiting time? What if he wanted to delay the attack even
further?
Imagine that Lucky Eddie keeps on counting until he gets to $9 \frac{7}{8}$. What strategy could
OF THE couNT
OTTACK THE wILL delay the attack even further?


Source: (Menezes et al., 2019)

These mathematical tasks were used at the end of primary school, with positive student engagement, facilitating discussion among students and promoting learning about rational numbers in a pleasant classroom climate (Menezes \& Ferreira, 2018; Menezes \& Alves, 2019). This use of mathematical tasks of a humorous nature is still seldom used. What happens in general, with the mathematics teachers of Portugal and Spain? Do they enjoy humour? Do they acknowledge its educational value? Do they use humour to teach maths? These are questions that this study seeks to answer.

\section{Methodology}

This study, which uses a mixed methodology (Bogdan \& Biklen, 2013: Gall et al., 2003), is based on the application of an online questionnaire that was used in Portugal and Spain. The questionnaire was answered by 1088 teachers (54.7\% of whom were Portuguese), from all levels of education, mostly female (82\%), with an average age of approximately 47 and with an average of 23 years of teaching practice.

The questionnaire consists of three parts: (i) Humour and sense of humour (three questions); (ii) Educational value of humour in mathematics teaching and learning (five questions); and (iii) The use of humour in mathematics teaching (three questions). The questions require closed answers (with a scale) and open answer (three questions). In this article, which is part of a larger study, we chose just a few of these questions: Sense of humour, educational value of humour, and use of humour to teach mathematics

\section{Results}

Most teachers (89.8\%) see themselves as persons who have a sense of humour, All teachers surveyed $(99.8 \%)$ value the existence of a sense of humour in others because it contributes to "managing difficult situations", "becoming more comfortable and relaxed", "adapting to everyday situations" and "being more productive at work". There were no significant differences between Portuguese and Spanish teachers, even though there was some prevalence among teachers of the early years of schooling.

Almost all teachers surveyed consider that mathematics teaching is compatible with the use of humour (98\%). Also, with regard to this question, teachers of the early years of schooling stand out from teachers at other levels of education. Teachers justify the use of humour in class by "facilitating the pedagogical relationship between teacher and students", "making mathematics more attractive", "stimulating mathematical thinking" and "facilitating mathematical communication".

Surprisingly, most teachers $(89.4 \%)$ report that they regularly use humour to teach mathematics. Teachers in the early years of schooling stress the purposes of "Motivate," "Think," and "Teach Concepts," while secondary school teachers emphasize the purpose of "Creating a Good Environment.".

At the end of the questionnaire, a comic strip was drawn (Figure 2) and teachers were asked: "Comment on the pedagogical value of this strip for teaching mathematics." This question, despite 
being open-ended, obtained a very high number of answers (70\%). Most teachers (about 90\%) recognize the educational value of the strip's humour, and found it interesting for teaching mathematics.

In their answers, teachers highlight the opportunities that the humorous strip gives to make students think and learn mathematics, that is, they underline the role of humour in developing cognitive competences (cognitive function).

The division of the unit into several parts and the parts which the unit has divided by eighths. The significance of values. The mixed numbers and their representation. The number of fractional elements up to 10 units. The geometric and algebraic representation. Among other explorations. (Q 78)

This humorous strip is intended for students to observe, compare and order rational numbers represented in different ways, to verify the position in a numerical line of a nonnegative rational number represented in its different forms, to interpret information and mathematical ideas represented by various ways to think about the usefulness of using fractions for counting before attacking the enemy (taking as long as possible). (Q 371)

Although in lesser numbers, teachers acknowledge the educational value of the strip which allows for communication and discussion and creates a positive learning environment:

It is a humorous, quite funny situation, it would certainly provoke laughter among the students, providing, right from the start, a pleasant working climate, as well as curiosity (...). (Q103)

Great comics to bring up a discussion centred on the density of the set of rational numbers. (...) I will see it explored in classes of the 5th and 6th grade. In either case, they start to laugh at Chiripita's "telling" but then start thinking about it, trying, for example, to decide whether the attack can be postponed indefinitely or not and why (Q2).

\section{Conclusion}

Like Martin (2007), when he says "many teachers tend to use humour quite frequently in classrooms settings" (p. 351), this study also shows that Portuguese and Spanish mathematics teachers use humour to teach mathematics. They do so because they value humour (theirs and others) and, essentially, because they acknowledge its pedagogical value. In commenting on Chris Browne's strip, they identify its educational value in teaching mathematics, highlighting the cognitive function as being more significant than the affective and communicative functions (Banas et al., 2022; Flores \& Moreno, 2011; Guitart, 2012; Guitart \&Flores, 2003).

Do Mathematics, humour and teaching, combine? To Portuguese and Spanish mathematics teachers, at all levels of education, it appears to combine. 


\section{Acknowledgment}

This work is financed by national funds through FCT - Fundação para a Ciência e Tecnología, I.P., under the project UID/Multi/04016/2016. Furthermore, we would like to thank the Polytechnic Institute of Viseu and CI\&DETS for their support. This is an outcome of the science project HUMAT: Humour in Mathematics Teaching (UID/Multi/04016/2016).

\section{References}

Adão, T. (2016). Os processos cognitivos subjacentes à apreciação do humor. Contributos para o professor/mediador de língua materna-português (Doctoral Thesis in Language Didactics, Faculdade de Letras, Universidade do Porto).

Banas, J. A., Dunbar, N., Rodriguez, D. and Liu, S. J. (2011). A review of humor in educational settings: Four decades of research. Communication Education, vol. 60, n. 1, pp. 115-144.

Bogdan, B. and Biklen, S. (2003). Investigação qualitativa em educação: Uma introdução à teoria e aos métodos. Lisboa: Porto Editora.

Flores, P. and Moreno, A. J. (2011). Matemáticamente competentes para reír. Barcelona: Graó.

Gall, M. D., Borg, W. R. and Gall, J. P. (2003). Educational research: An introduction. 8th ed. Boston: Allyn and Bacon.

Guitart, M. (2012). Permitido reír... Estamos en clase. El humor como recurso didáctico en aula de Estadística (Doctoral Thesis, Universidad Nacional de Cuyo, Mendoza, Argentina).

Guitart, M. and Flores, P. (2003). Humor gráfico para la enseñanza y el aprendizaje del azar. Suma, vol. 42, pp. 81-89.

Martin, R. (2007). The psychology of humor - An integrative approach. London: Elsevier Academic Press.

Martins, A. I. (2010). A seriedade do humor ao longo dos séculos: uma retórica do poder político ou de um contra-poder?. Revista Iberoamericana de Estudios de Desarrollo, vol. 4, n. 1, pp. 323346.

Menezes, L. and Alves, R. (in press, 2019). Números racionais e discussões matemáticas: Uma tarefa de cunho humorístico no 5. ${ }^{\circ}$ ano. In E. Mamede, C. Monteiro and H. Pinto (Eds.), Contributos para o desenvolvimento do sentido de número racional. (pp.). Lisboa: APM.

Menezes, L. and Ferreira, F. (2018). Humor no ensino da Matemática: Oportunidades para a aprendizagem. Educação e Matemática, 149/150, pp. 53-59. 
Menezes, L., Gomes, H., Ribeiro, A., Martins, A. P., Flores, P., Viseu, F., Oliveira, A., Matos, I. A., Balula, J. P. and Delplancq, V. (2017). Humor in Mathematics Teaching: Tasks for the classroom. Viseu: LitoPrint and ESEV.

Meyer, J. C. (2015). Understanding humor through communication: Why be Funny, Anyway?. Lanham: Lexington Books.

National Council of Teachers of Mathematics (NCTM) (2007). Cartoon corner: Humor-based mathematics activities (Edited by A. Reeves). Reston, VA: National Council of Teachers of Mathematics.

National Council of Teachers of Mathematics (NCTM) (2013). Cartoon corner 2: Humor-based mathematics activities (Edited by P. House). Reston, VA: National Council of Teachers of Mathematics.

Perks, L.G. (2012). The ancient roots of humor theory. International Journal of Humor Research, vol. 25, n. 2, pp. 119-132.

Shmakov, P. and Hannula, M. S. (2009). Humour as means to make mathematics enjoyable. Proceedings of Sixth Congress of the European Society For Research In Mathematics Education. Lyon, France, pp. 144-153. 